\title{
Daniel Fairfax
}

\section{A képek világában élünk. Interjú Dana Polannel}

\section{Szerzô}

Dana Polan a New York-i Egyetem Filmtudományi Tanszékének professzora, a film és a televízió elismert kutatója. 1980-ban szerezte meg PhD-fokozatát a Stanfordon, és 1985-ben doktorált az Université de la Sorbonne-Nouvelle-en. Megjelent könyvei: The Politics of Film and the Avant-Garde (1984), Power and Paranoia: History, Narrative and the American Cinema, 1940-1950 (1986), Scenes of Instruction: The Beginnigs of the US Study of Film (2007) és Julia Child's The French Chef (2011). Irt a Magányos helyen-ról, a Ponyvaregényrôl, Jane Campionról és a Maffiózókról. Az amerikai mozit tárgyaló munkái mellett a francia filmelmélet és filozófia elkötelezett kutatója, angolra fordította Gilles Deleuze és Félix Guattari Kafka - A kisebbségi irodalomért címú könyvét. 1998-ban a francia kormány kitüntette az Ordre des Arts lovagja címmel, 2003-ban pedig kutatóként bekerült a Filmmúvészeti és Filmtudományi Akadémiába.

https://doi.org/10.31176/apertura.2019.14.3.1 


\section{Daniel Fairfax}

\section{A képek világában élünk. Interjú Dana Polannel}

Daniel Fairfax: Különösen hosszú ideje foglalkoztatja a közvéleményt a mozi halálának kérdése. Évtizedek óta benne van a köztudatban, s még a mozi életben maradását is túléli. Majdhogynem a vallási szekták bejelentéseihez hasonlithatnánk, miszerint a világ egy bizonyos napon véget fog érni, s amikor mégsem ér véget, kitolják a dátumot. Mit gondol erról a trópusról?

Dana Polan: Úgy gondolom, hogy ez egy trópus és egy gesztus. Általában is lenyügöznek az apokaliptikus tartalmú nyilatkozatok. A mozi halála típusú gondolat mellett számomra épp olyan érdekes a humán tudományok válságának a gondolata (mivel én magam is kutató vagyok). Ez a dolog gyakran ciklikus jellegú, jön egy bejelentés, hogy valamilyen apokalipszis közeledik, amire érkezik egy cáfoló reakció, helyesbítés, figyelmeztetés, majd az egész újrakezdődik. Ez azért is lehet, mert az adott diszkurzusnak szüksége van erre a krízistudatra az önfenntartáshoz. A vallási szekták említése azért érdekes, mert a mozi haláláról szóló beszámolók megszaporodtak a 20. század végén. Sokan beszélnek az ezredvégi gondolkodásról, és arról, hogy a messianisztikus vonatkozások nem csak a századfordulók, hanem az ezredforduló kapcsán is felszínre jönnek. Frank Kermode Sense of an Ending címú könyvében sok szó esik arról, mi történt 1000-ben, és hogy mi történhet 2000-ben. A mozi halála tehát egyúttal a múvészet századának halála, ugyanakkor a millennium halála és sok minden más is, például Y2K ${ }^{[1]}$ és így tovább. A mozi haláláról szóló siránkozás az általános szorongás részét képezi. A Film Criticismbe írtam egy rövid esszét [2], ahol azt állítottam, hogy akik a mozi haláláról beszélnek, mint például Susan Sontag, valójában egy bizonyos fajta mozi haláláról beszélnek, amely kedves volt számukra, egy bizonyos fajta tartalomról, az európai vagy ázsiai múvészfilmrôl és a bemutatás egy bizonyos módjáról, amikor még moziban nézték a filmeket. Nem igazán vagyok jövóbelátó, de azt gondolom, hogy a mozgóképkultúra nem tûnik el. Teljesen világos, hogy mindig lesznek különbözô módok arra, hogy az emberek mozgóképeket fogyasszanak. De még a sontagi értelemben sem biztos, hogy a múvészmozi megszúnik. Lehet, hogy megváltozik, és kiderül, hogy másféle platformokra is szükség van. Azok a filmek, amelyeket korábban az IFC-n [fizetôs, amerikai kábelcsatorna] vagy a Film Fórumon [függetlenfilmes vetítôhely New Yorkban] mutattak be, most a Netflixen és más streaming szolgáltatóknál tekinthetôk meg. És nyilvánvalóan a mozielőadás sem tûnik el. Az az elképzelés, hogy az emberek már nem járnak moziba, és hogy a filmek már csak máshogyan kerülnek forgalmazásra, nem teljesen igaz. Vannak filmek, amelyeknek a mozibemutatása még mindig jelentôs esemény. Nem hiszem, hogy ezek közül bármelyik is eltúnne. Feltételezem azonban, hogy sok minden, amirôl a filmrôl szóló diszkurzusokban szó esik, vagyis a válság és halál fogalmainak a használata, épp a diszkurzus folytatódását teszi lehetôvé. 


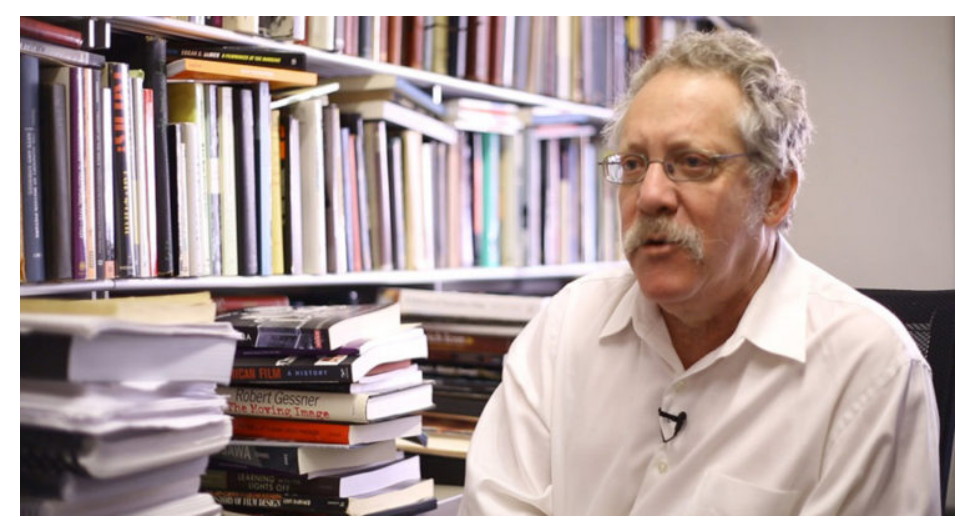

Dana Polan

DF: Ez elég paradox.

DP: Az lenne, ha nem tennénk különbséget filmtudomány és film között. Ezeknek nem feltétlenül kell egybeesniük. Vannak tudományterületek, amelyek holt formákat tanulmányoznak. A szláv tanszék vezetôje a Yale-en, a középkori orosz irodalom kutatója egy korábbi beszélgetésünkben azt mondta: „Én vagyok az utolsó kutatója a középkori orosz irodalomnak az USÁ-ban. A hatvanas éveim elején járok, tehát két dolog történhet: vagy nyugdíjba megyek, vagy meghalok. És amikor ez megtörténik, ez az aldiszciplína megszúnik. Senki sem foglalkozik már vele.”

DF: Ez olyan, mint amikor egy nyelv utolsó beszélöje meghal.

DP: Pontosan. Egy tudományterület tehát eltúnhet. A filmes diszkurzus véget érhet akkor is, ha a mozgóképkultúra folytatódik. De a filmtudomány eltûnése nem fog bekövetkezni. A diszkurzus azért hozza létre a válságot, hogy maga a diszkurzus folytatódhasson. A humán tudományok kifejezetten értenek ehhez. Nemrég olvastam egy kéziratot, amely a humán tudományok válságáról szól - ebben az esetben maga a válságról való beszéd teszi lehetôvé az újabb szöveg megírását. Jelenleg Howard Hawks-ról tartok kurzust, és az, ahogyan mindig új szövegeket generálunk, hogy a diszkurzust folytathassuk, nagyon hasonló ahhoz, ahogyan a Hawks-ról szóló kritika kibontakozott. Ott az elsô úttörô szöveg, majd valaki kritizálja vagy kibővíti, majd, amikor a diszkurzus történetivé válik, valaki ír egy összefoglalást a vitákról. Azután az összefoglaló esszé lesz az, amelyet valaki kommentálni fog. Tehát a diszkurzus önmagát generálja. Jóformán minden esszé úgy kezdődik, hogy „Elôször a Cahiers du cinéma fedezte fel Hawks-t, aztán Robin Woods ezt állította, majd Peter Wollen ezt tette.” Tehát maga a tény, hogy a diszkurzus megsokszorozódik, szaporodást generál. 


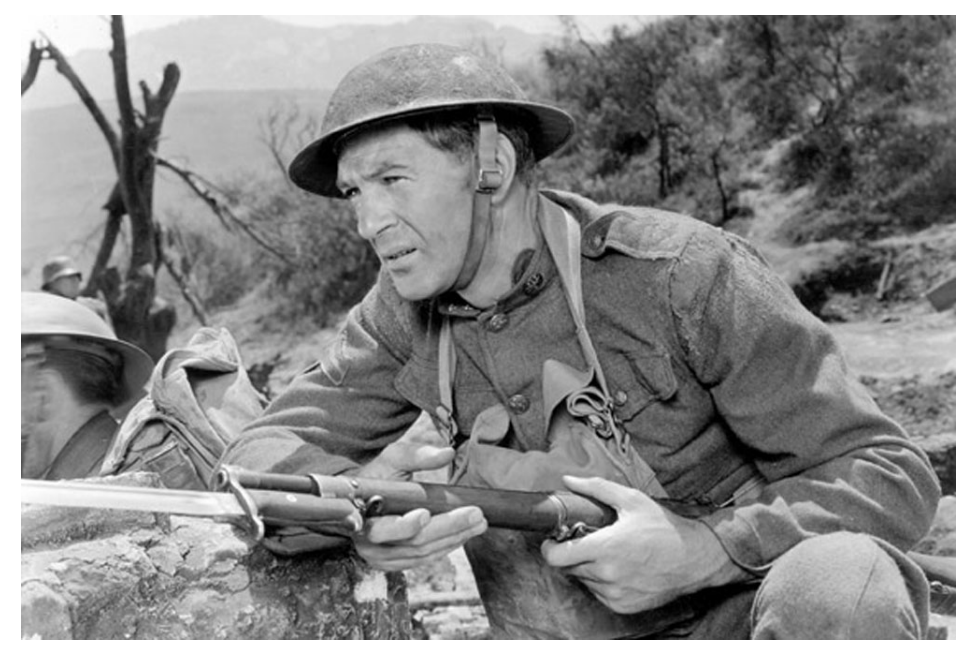

York örmester (Sergeant York. Howard Hawks, 1941)

DF: Kicsit úgy hangzik, mint ahogyan a középkori szerzetesek a vallásos kéziratok átiratait készitették.

DP: Az igazat megvallva, Laura Mulvey-t rendkívül fontosnak tartom, de már nem vagyok hajlandó elolvasni a Mulvey-t értelmezố tizedik esszét. Egy idô után már nem lehet sok újat mondani, csak annyit, hogy összefoglaljuk a korábbi szakirodalmat, és valamilyen csekély módosítást javaslunk a korábbiakhoz képest. És ez talán közelebb visz a filmtudományhoz: ahelyett, hogy egy új metadiszkurzust hoznának létre, általában egy új esettanulmánnyal módosítják a diszkurzust, vagyis az eredeti gondolatot ott alkalmazzák, ahol korábban még nem használták. Ami így létrejön: kezdetben volt Mulvey, aztán jött Williams, aztán Doane, de egyikük sem alkalmas az elmúlt évek nôi filmjeinek megközelítésére (ami túl könnyú megoldás), és láthatóvá válik, hogyan bújik ki a mai mozi azon modellek fennhatósága alól, amelyeket ôk felállítottak. Az esettanulmányok írása néha a diszkurzus folytatása, miközben úgy teszünk, mintha valami mást csinálnánk. Sok esettanulmányt tehát a kivételesség vezérel: itt a dolog, amely nem illeszkedik a diszkurzus végtelen láncolatába. Valójában csak hozzáad a diszkurzushoz, és hozzájárul annak öngenerálásához. Ez pedig a filmtudomány jövőjének kérdésére is vonatkozik. A diszciplínák, amikor elindulnak, önfenntartásra rendezkednek be. A film kutatása nem túnik el csak úgy. Amikor a dolgok intézményesülnek, továbbra is folytatódnak, hacsak nem szüntetik meg ôket vagy nem változnak. De ha egyszer elindulnak, olyan hajtóerejük van, amelyet nehéz megállítani.

\section{DF: Ez intézményes vagy diszkurzív természetü?}

DP: Azt gondolom, hogy mindkettô. Nem biztos, hogy különbséget tennék köztük, mert az intézmény szerepe, hogy elömozdítsa a diszkurzust - különösen a humán tudományokban. Véleményem szerint mindennek megvan a jó oldala is. De a publikálj vagy pusztulj [publish or perish ] alternatívái vagy a kinevezés publikáláshoz kötöttsége arra sarkalja az egyetemeket, hogy a tartalom vagy minôség bármilyen megvitatása elôtt kvantitatív követelményeket állítsanak fel: az elôrehaladás feltétele bizonyos hosszúságú könyv vagy bizonyos számú cikk. Ez automatikusan a diszkurzus továbbgenerálására ösztönöz. Szerintem az állandó kinevezésre szükség van, de 
mindenkit a tudomány számszerúsítésére kényszerít. [3]

DF: A kutatás inflálásával is együtt jár. Már lehetetlen, hogy egy területröl teljes képet alkossunk egyszerüen azért, mert túl sok az információ.

DP: Igen. Sokat olvasok, de vannak pillanatok, amikor úgy érzem nehéz lépést tartani, vagy nem egyértelmú, hogy tényleg el kell-e olvasni Mulvey-ról a tizedik esszét is. Az egyik érdekes fordulat a humán tudományok válsága kapcsán, hogy az erőforrások csökkentése még több dolgot eredményezett: több folyóiratot, több publikációs helyet, miközben nincsenek közös platformok. Az Egyesült Államok minden kutatója elmegy az SCMS [Society for Cinema \& Media Studies] konferenciájára, a Cinema Journal a társaság folyóirata, de egyre inkább ez az a fajta folyóirat, amelyet, miután megkaptad, rápillantasz, majd felteszed a polcra. Valószínúleg nincs két olyan kutató egy és ugyanazon tudományterületen, aki ugyanazt a két folyóiratot olvassa. A legutóbbi SCMS-en huszonkét szekció volt egyidejúleg. Emlékszem, amikor 1980-ban rendeztük az SCS [Society for Cinema Studies] konferenciáját (akkoriban így hívták), az egyik célunk az volt, hogy ne legyen két olyan szekció egy idóben, amelynek a témája egybeesik - ma ez lehetetlen. Nagyon kedvelem az új filmtörténetet, amely a konkrétról, a materiálisról, a kontextuálisról szól, de azt hiszem, az egyik eredménye, hogy végtelen diszkurzust generál. Egy idô után nem tesz mást, mint hogy rengeteg példát hoz, amelyekból nem következtet valami általánosabbra. Az empirikushoz való visszatérés tanúi lehetünk, ami egyrészt ugyan megalapozza a kutatást, ugyanakkor hiányzik belôle az átfogó magyarázat, hogy valami miért hasonlíthat valami másra, mivel a különbségre fekteti a hangsúlyt. Ha túlságosan beleveszel a részletekbe, szem elôl téveszted az átfogó képet. Ha megrekedsz ott, hogy egy dolgot egyediségéért, önmagáért tanulmányozol, sosem tudod egy magasabb szinten tárgyalni. Például a bemutatás tanulmányozása [exhibition studies] kezd ilyenné válni.

DF: Azért is történik mindez, mert halmozzák az adatokat, és egyre inkább adatokat dobálnak, nem pedig az adatok értelmén gondolkodnak.

DP: Idônként talán nem is az adatok halmozásáról van szó, hanem az abba vetett hitrôl, hogy még rengeteg adat van feltáratlanul. Meglepőnek találom, hogy sok közönségkutatás mennyire korlátozott adatkészlettel dolgozik. Ezek a mikrokutatások rendkívül limitáltak hatókörüket tekintve, és talán nem is jellemzôek a tágabb képre. Vagyis sok adat van, nehéz lépést tartani, de egyre kevesebb és kevesebb tekinthetố közülük hasznosnak. Ezt visszaigazolják azok a kutatók is, akik a saját generációmhoz tartoznak, akik egyetértenek avval, hogy sok elôadást azért nem hallgatunk meg az SCMS-konferencián, mert túlságosan is trendin vannak megfogalmazva. Egy ideális világban talán az összes könyvet el akarnánk olvasni, de a valóságban csak nagyon keveset tudunk elolvasni közülük. Nem akarok túl konzervatívnak tûnni, mint azok, akik szerint nincs szükség Buffy, a vámpírok rémével foglalkozó kutatásokra, de kérdés, hogy egy idő után lehet-e még újat mondani. Mindig meglepődök, amikor kijön egy újabb, film noirral foglalkozó könyv. Mit lehet még mondani róla? 
DF: Ennek ellenére ebben a szemeszterben még mindig Howard Hawks-ot tanit. Egyes anyagok kimeríthetetlenek, ugyanúgy, ahogy Shakespeare-t ötszáz év múlva is fogják tanítani.

DP: Egyre inkább a tanításra koncentrálok, és olyan dolgokat akarok tanítani, amelyek szórakoztatnak. A következő félévben Frank Sinatra kurzust fogok tartani. Hawks számomra rendkívül tanítható, jó lehetôség, hogy olyan kérdésekről beszéljünk, mint a szerzôség, a kultúra, a maszkulinitás. Számomra a tanítás az a hely, amelyben a diszciplína jövőjét látom. Van egy régi vicc, ami szerint, ha megkérdezel egy kutatót, hogy min dolgozik, sosem azt mondja, hogy mirôl szól a kurzusa, hanem hogy mirôl szól a tanulmánya. Annak ellenére, hogy meglehet, csak három ember olvassa a tanulmányát. Sok tanár számára a tanítás csupán másodlagos, de számomra épp olyan érdekes tanítani, mint kutatni. Érdekes, hogy milyen kevéssé számít az egyetemi kinevezésben az oktatói tevékenység. Az olyan helyeken, mint a Harvard, van egy régi vicc, miszerint, ha elnyersz egy oktatói díjat, akkor harangoztak a kinevezésednek, ugyanis ez azt jelenti, hogy nem vagy komoly kutató. Sokat gondolkodom a tanítás szerepéról, talán amiatt, ahol most tartok a pályámon. Nem csak a humán tudományokra érvényes mindez. A természettudományokban is három és fél ember olvas el egy tipikus cikket. Senki sem tud mindent követni egy diszciplínán belül, sôt egy aldiszciplínán belül sem. Tehát nincs többé átfogó nézôpontunk. Inkább sok területrôl tudjak kevesebbet, minthogy egyetlen területre specializálódjak. Vannak kivételek, néha találkozol olyannal, aki mindent elolvasott, és mindent tud, de ez egyre ritkább és ritkább.

\section{DF: Egyaránt foglalkozik a klasszikus mozival és a televizióval is. Hogyan látja a két különbözó terület} együttmúködését a kutatásában?

DP: Szerencsére minden intézmény, ahol eddig dolgoztam, lehetôvé tette, hogy én válasszam meg a saját területemet. Senki sem mondta, hogy franciás kutatóként semmi mással nem foglalkozhatok. A második világháború utáni amerikai film kutatójaként tartanak számon, de nem korlátozom magam erre. Amikor a Pittsburgh-i Egyetemen voltam, az volt az egyértelmú elképzelés, hogy senki nem birtokolja a kurzusokat. Ha az ember meg tudta indokolni, akármilyen kurzust tarthatott. Mindig is szerettem arra használni a tanítást, hogy egy érdeklődési területen elmélyülhessek. A tanítás számomra gyakran lehetôség arra, hogy új témákkal foglalkozzak, és a magam számára is új felfedezéseket tegyek. Bizonyos dolgokhoz idônként vissza-visszatérek. Például az a kurzus, amelyet az amerikai frankfurti iskoláról tartok vagy az amerikai film általános áttekintéséról szóló kurzusom, de ezek folyamatosan változnak, változnak a filmek, változnak az olvasmányok, és én is másképp gondolkodom róluk. Amennyire csak tudok, próbálok lépést tartani az új irodalom egy részével. Ez a rendszeres kiindulópont. A következó évben valamikor valószínúleg tartani fogok egy kurzust Benjamin Árkádok-tervezetérôl. A kurzusok alkalmat adnak arra, hogy folytassam a kutatást. Egy olyan korban, amelyben semmit sem lehet lefedni, szeretek széles látókörú lenni, szeretek kockázatot vállalni. Inkább vagyok vállalkozó szellemú és követek el hibákat, minthogy egyáltalán ne változzak. Az egyetlen eset, amikor úgy gondolom, valóban túlvállaltam magam, a BFI-nak [British Film Institute] készített könyvem volt Jane Campionról. 


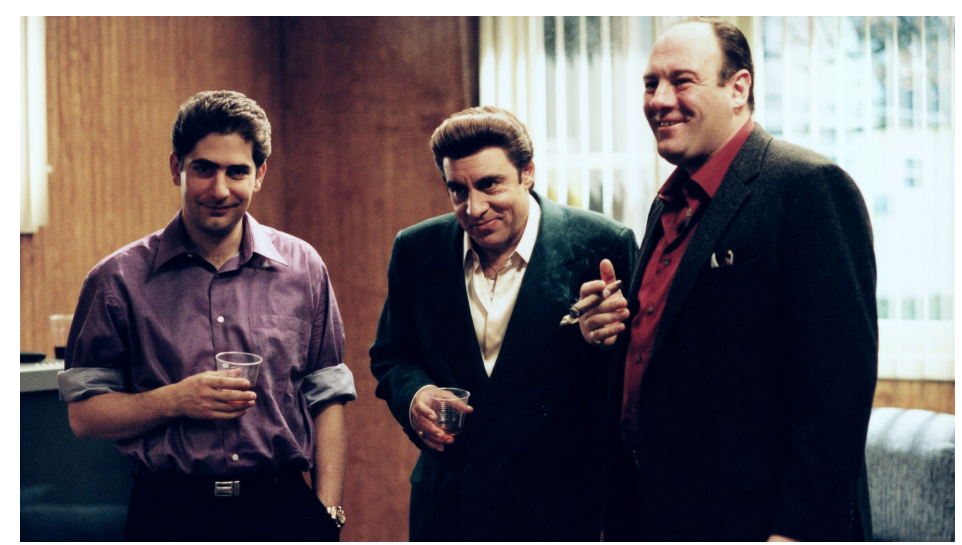

Maffiózók (The Sopranos. 1999-2007)

DF: Azért, mert úgy érezte, nem ismeri eléggé a kulturális kontextust?

DP: Igen. Úgy gondolom, mondtam pár érdekes dolgot a Zongoraleckérôl (The Piano. Jane Campion, 1993) és arról, hogy egy bizonyos fajta közönség miért kedvelheti annyira. Egy kissé leegyszerúsítve ezt a közönséget a diplomás nôk alkotják, akik szeretik a múvészmozit, ugyanakkor szeretik bizonyos anyagok fenomenológiáját, mint a szél, a homok és a víz, amire a film nagyon is rájátszik. Azért volt fontos számomra a könyv megírása, mert elgondolkodtatott a közönségrôl. Az egyik következô írásom a Maffiózókról (The Sopranos) szólt, amiben azt tárgyaltam, hogy a Maffiózók hogyan találkozik egy bizonyos típusú célközönséggel: a városi diplomással, aki valami provokatívat akar, ez az HBO jellemzô célcsoportja. Ez jó alkalom volt számomra, hogy a beleértett nézôrôl, a nézô szövegbe íródásáról gondolkodjak. A Maffiózók egyértelmúen egy bizonyos fajta nézôt képzel el magának. Azért érdekes a músor, mert egy olyan világ fölé helyez minket, amelyet azért élvezni is akarunk. Sosem mennénk el egy New Jersey-i sztriptízklubba, de láthatjuk, s az érzékek útján részt is vehetünk benne. A Melfi-karakter az HBO közönségét helyettesíti. A munkám úgy alakult, hogy szerencsés módon azt kutathatom, amit csak akarok. Az életrajzomban semmi sem jelezte, hogy a következő írásom Jane Campionról szól. Visszatekintve látom, hogy a közönségrôl szólt, de azt nem gondolom, hogy eleget tudtam Ausztráliáról vagy Új-Zélandról ahhoz, hogy jól csináljam meg. De inkább élek a lehetôséggel, és hibázom, minthogy meg se próbáljam.

DF: Érdekes, hogy sokkal inkább szükségét érezzük egy munka kulturális kontextualizálásának, ha egy olyan „kisebb” kultúráról van szó, mint Ausztrália, de nincs bennünk ugyanez az aggály, amikor például Prousttal foglalkozunk. Vajon ehhez nem kell ismernünk a századvégi Párizst kívülrôl-belülrôl?

DP: Nem akarom a Jane Campionról szóló könyvemet felületesnek nevezni, de nem gondolom, hogy megvolt a kellô tudásom ahhoz, hogy olyan alapos legyen, amilyen lehetett volna. 


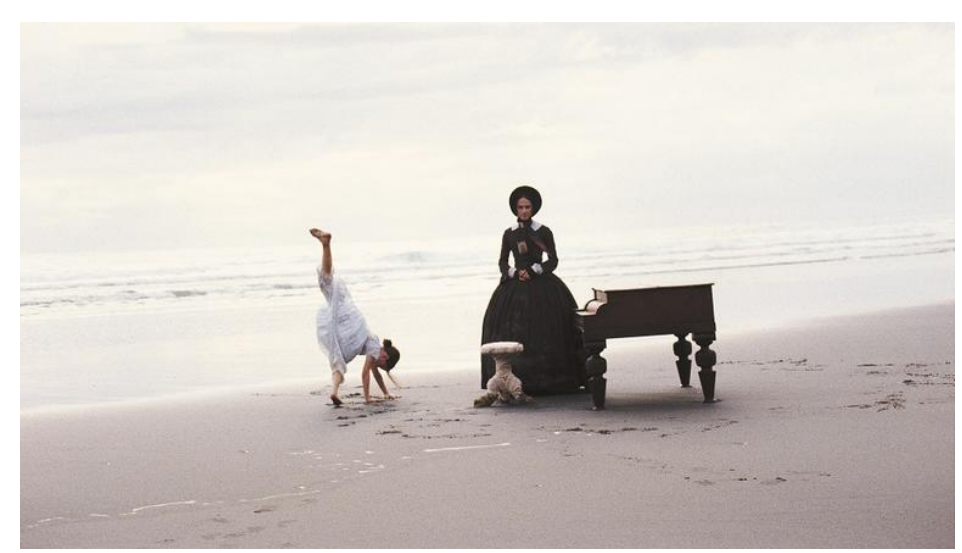

Zongoralecke (The Piano. Jane Campion, 1993)

DF: Ennek ellenére Campion olyan müvész, aki univerzális kérdésekról tud beszélni.

DP: Igen, a könyv végén nem úgy beszélek róla, mint egy ausztrál, hanem mint egy posztnacionális rendezőről, aki a nemzetközi múvészmozis térben mozog. Ez így igaz, ugyanakkor ez annak a legitimációja is, hogy miért nem foglalkozunk sokat Ausztráliával. Szeretek tehát kockázatokat vállalni, és új területekre merészkedni, de ezt a kelló alapossággal és szakértelemmel szeretném tenni. Nem kedvelem azokat, akik felületesen foglalkoznak egyes területekkel, föleg, ha atyáskodó leereszkedéssel teszik azt. Sokan azt gondolják, hogy a filmrôl nyugodtan beszélhetnek, ha irodalommal vagy filozófiával foglalkoznak. És néha egyszerúen nem néznek utána a dolgoknak. Cavell elképesztôen fontos a területen, de akkor is aggasztónak találom, hogy a screwball comedy-vel foglalkozó könyvében, a Pursuits of Happiness-ben nem említ meg egyetlen másik szerzôt sem, akik ugyanazokról a filmekrôl írtak, ez pedig a kritikai irodalom szándékos figyelmen kívül hagyása. Örülnék, ha az emberek megcsinálnák a házi feladatukat. Évekkel ezelôtt egy volt kollégám barátja azzal hívott fel, hogy a dékán megbízta, tartson egy kurzust Shakespeare és a film témában. Azt kérdezte tôlem, hogy milyen filmeket kéne tárgyalni. De ha én hívnék fel egy Shakespeare-kutatót azzal, hogy Shakespeare-kurzust kell tartanom, mit tanítsak, mélységesen megsértôdne. Nem érzik úgy, hogy ez a film területén is sértő. Állandóan kérnek, hogy tanítsak a francia filmrôl, de sosem foglalkoztam a francia mozival. Idônként felkérnek, hogy bíráljam el a francia film oktatására felkért jelöltek pályázatát. Egy Proust-kutatót nem kérnek fel, hogy értékelje Chandlert. A múltkor nálunk volt Nicholas Baer, aki a német filmes diszkurzusról szóló új antológia, a The Promise of Cinema egyik szerkesztôje. Kracauerrôl tartott elóadást az NYU-n. Én pedig arra gondoltam, hogy Kracauerról remek lenne kurzust tartani. De nem tudok németül, a német kiadás pedig húszkötetes. Tehát nem fogok róla kurzust tartani. Többet fogok Kracauertól olvasni, szeretek olvasócsoportokat tartani, de ezt a fajta kockázatot nem vállalom.

Írtam pár könyvet a televízióról. De nem gondolom, hogy a filmtudomány és a filmkritika [film appreciation] ugyanaz lenne. A tudomány és a kutatás nem az izlésünkrôl szól. Tudományosan írni nem arról szól, hogy mit kedvelsz. Esetleg kedvelheted, amiról írsz. Szeretek Hawks-ról tanítani, de nem kedvelem a rossz filmjeit, és a legtöbb Hawks-filmmel vannak ideológiai problémáim. Tényleg úgy gondolom, hogy ez a kritikai diszkurzus lényege. A Ponyvaregényról szóló 
könyvemból nem derül ki, hogy kedvelem-e a filmet vagy sem. A könyv vége felé elemzem azoknak a véleményét, akik üres posztmodernizmusként látják, de még ott sem mondom meg, hogy én annak tartom-e vagy sem. Nem hiszem, hogy a kutatás arról szól, hogy rokonszenveinkkel és ellenszenveinkkel tüntetünk. Nem arról írunk, amit szeretünk, bár adhat neki lendületet, de önmagában nem ez kritikai elmélet lényege.

DF: Engem azért foglalkoztat a kérdés, amikor SCMS konferenciákon veszek részt, vagy cikkeket olvasok, hogy az emberek valójában élvezik-e, amit csinálnak. A kutatás tárgya iránti szenvedély hiánya néha rendkivül szembeszökö.

DP: Számomra szinte az ellenkezôje a kérdés: akkor is ezt az előadást tartanák, ha nem kedvelték volna a filmet? Sokszor vagyok felvételi bizottságok tagja, és az alap- és mesterszintekre való jelentkezéskor, de néha még azután is, gyakran találkozom olyan megnyilvánulásokkal, amelyek úgy kezdôdnek, hogy „Szeretem a filmeket, és azért akarok az NYU-ra jönni, hogy tovább mélyítsem a filmek iránti érdeklődésemet." Meg kellene kérdeznem egy kémikust errôl, de nem tudom elképzelni, hogy a kémia területén gyakran lehetne olyanokkal találkozni, akik azt mondják, hogy „Imádom a molekulákat”, vagy „Imádom a nitrogént”. Szinte már jobban értékelnék egy olyan jelentkezést, amely úgy kezdődik, hogy „Utálom a filmeket, és azért akarok az NYU-ra jönni, hogy megértsem, hogyan múködnek a filmek ideológiai apparátusként, vagy olyan ígéretként, amely sosem teljesült be." Ha már errôl van szó, én magam is részben amiatt fordultam a televízió felé, mert csalódtam a kortárs Hollywoodban. Ehhez képest a Maffiózók olyan músor volt, amit néztem, és amely érdemesnek tûnt arra, hogy írjak róla.

DF: Elképzelhetố, hogy a filmes háttér arra trenírozta, hogy másként lásson dolgokat, mint azok, akik a televizió-tudomány felól érkeznek, és akik nem rendelkeznek ugyanazzal az akkulturációval? A klasszikus zene hallgatóihoz hasonlóan, akik arra trenírozzák a fülüket, hogy másként halljanak.

DP: Teljes mértékben. A Maffiózók azért érdekes, mert megmutatta a film korlátait fóként a narratívával kapcsolatban. A karakter- és történet-vezérelt kultúrában ma már sok minden átkerült a televízióba.

DP: A televizió regényszerü kultúra.

DP: Igen, tizennégy epizódban olyan karakterfejlődés lehetséges, ami egy kétórás filmben valószínúleg nem lenne lehetséges. Ezzel szemben a kétórás film már inkább elsôsorban az effektekrôl, a szenzációról szól, nem a karakterekről. A Cápa (Jaws. Steven Spielberg, 1975) végülis a cápával való fizikai találkozásról szól. A közönség ezt élvezheti, de én nem élvezem. A karakterfejlődés tehát gyakrabban történik meg a tévében, mint a filmben. Vannak persze kivételek. Csodálkozom, hogy minden évben van egy-két karaktervezérelt film, amelyet Oscarra jelölnek a forgatókönyvért, a színészi játékért, de más kategóriában nem igazán jelölik. Lonergan például mestere a karaktervezérelt filmeknek. Vagy Derek Cianfrance Kék Valentinja (Blue Valentine. Derek Cianfrance, 2010) szépen megírt kis film az emberekröl. 


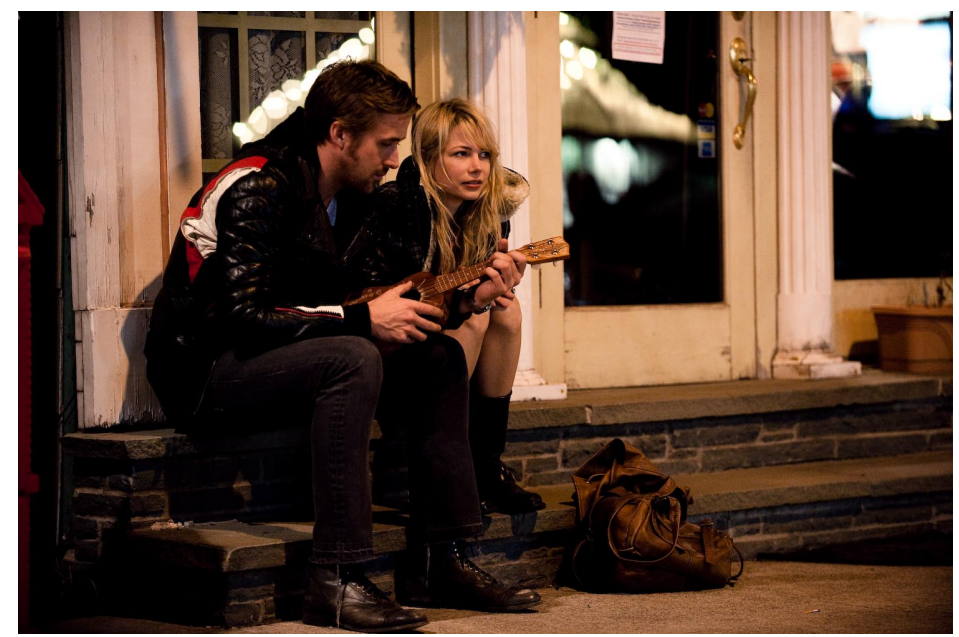

Kék Valentin (Blue Valentine. Derek Cianfrance, 2010)

DF: A munkái közül számomra az egyik legérdekfeszitóbb Az oktatás színterei [Scenes of Instruction] . Több okból kifolyólag is. Egyrészt, mert lerombolja azt a széleskörü nézetet, hogy 1970 elôtt nem létezett filmtudomány. De ennél is fontosabb, hogy lát-e párhuzamokat a könyvben vizsgált periódus (1920-as és 1930-as évek) és napjaink között? Talán nem annyira intézményi szinten, hanem a kutatók tekintetében, akik az új jelenségekkel küzdenek.

DP: Az egyik legfontosabb dolog a könyvben, hogy fốként tanárokról szól. Nagyon kis része szól csak olyanokról, akik nem úgy tanulmányozták a filmeket, hogy közben tanítottak volna. Ez egy olyan könyv, amely nem annyira a filmmel foglalkozó értelmiségiekrôl szól, hanem sokkal inkább a filmmel foglalkozó kutatókról. Számomra nagy és lehangoló felfedezés volt, amikor rájöttem, hogy nem csak kutató, hanem egyetemi oktató is vagyok. A kettố pedig nem teljesen ugyanaz. Egyetemi oktatónak lenni azt jelenti, hogy vállalod az intézmény összes kötelezettségét, problémáját és terhét. Rengeteg idô megy el arra, amit az egyetemi oktató olyan ügyekkel és bizottságokkal tölt, amelyeknek semmi köze a kutatásához vagy a tudományos terveihez.

DF: Az egyetemi bürokrácia olyan, mint egy parazita, amely csak növekszik és növekszik a gazdatest terhére.

DP: Így van. Az egyetemek egyre több és több adminisztratív pozíciót hoznak létre. Amikor a Stanfordon voltam, megtudtam, hogy van egy egyetemi „bizottságok bizottsága”. Elôször meglepôdtem rajta, de késôbb azt gondoltam, hogy erre szükség van. Tehát szét kell választanod a kutató éned attól az énedtól, amelyiknek minden mással kell foglalkoznia: katalógust vezetni, diplomaosztó ünnepségre menni, minden olyan dolog, ami elvon a kutatástól. Az oktatás színterei tehát számomra egyértelmúen az egyetemrôl szólt. Olyan emberekrôl írtam, akiket azért vettek fel az egyetemekre, hogy kurzusokat tartsanak. Szerettem volna megtudni többet arról, hogy mi zajlott az órákon - ezt nagyon nehéz rekonstruálni. Ehhez a legközelebb abban a fejezetben jutottam, amelyik a syracuse-i Sawyer Faulkról szól. Találtam egy említést arról, hogy az 1930-as években volt egy filmkritikai kurzus Syracuse-ban, és úgy gondoltam, nem fogok sok mindent találni róla, de volt egy pár szabad napom, így vonattal Syracuse-ba utaztam, és az archívumban megtaláltam Sawyer Faulk hagyatékát. Faulk mindent megörzött, még a diákok dolgozatait is az 
osztályzatokkal együtt a harmincas évekből. Megórizte az összes előadása jegyzetét. Rekonstruálni tudtam az osztálytermi anyagot. Számomra tehát ez egy olyan könyv, amely arról szól, ami a tantermekben történik, és ami a tanterem és a tágabban értett világ között folyik: az egyetemi bürokrácia rétegeivel és hasonlókkal.

Személy szerint utálom a tudományos élet ezen részét. Az érdekel, ami az egyetemen túlnyúlik. Próbálok olyan dolgokat csinálni, amelyek túlmutatnak az egyetemen. A közértelmiségi [public intellectual] túl nagy szó, de csinálok DVD-kommentárokat, melyeket, mint az ismeretterjesztés egy fajtáját, rendkívül komolyan veszek, írok a BFI-nak könyveket, ami szintén az akadémián kívüli világnak szól. A Julia Childról szóló könyvemról közép-nyugati nôk írtak a gasztrokultúra szemszögéből, aminek nagyon örültem. A közönséggel - az unalmas akadémiai bizottságok tagjain kívül - az osztályteremben vagy a tágabb nyilvános szféra tereiben találkozol. Howard Hawks-ról beszélek a tanteremben, vagy meghívnak egy rádióba, hogy beszéljek róla, de elképesztô, hogy szinte esélytelen, hogy egy másik oktatóval folytassak ilyen beszélgetést. Elképesztô, hogy a tanárokkal semmilyen intellektuális dologról nem beszélgetünk. Beszélünk bürokratikus ügyekrôl, tananyagról, felvételiról, az alkalmazottak és a hallgatók megtartásáról - de nagyon ritkán beszélünk a kutatásainkról. Nagyon ritkán cserélünk véleményt a kutatásainkról, ez csakis egyéni szinten történik. Az egyetemi struktúra nem errôl szól. Szóval ami miatt érdekes volt Az oktatás színterein dolgozni, hogy a tanteremrôl szólt, és semmiképpen sem idealizálnám az egyetem bürokratizálódása elôtti aranykorként, de feltûnt, hogy ezen alakok közül nagyon kevesen gabalyodtak bele a bürokrácia útvesztôjébe. Nem úgy tekintek erre a könyvre, mint ami a filmtudomány történetével, hanem ami ennek elôtörténetével foglalkozik. Ekkor még nyoma sem volt annak az érzésnek, hogy a diszciplína mekkora teher, és mivel még nem jött létre a diszciplína, azt csinálhattak, amit akartak, viszonylagos szabadságuk volt, nyiltan kísérletezhettek. Néha az útjaik keresztezték egymást, a legtöbbjük viszont egymástól teljesen függetlenül dolgozott. Nem volt éves SCMS-ük, ahova menniük kellett volna. Úgy dolgoztak, hogy szó szerint nem tudtak egymásról. Nem volt közös kultúrájuk vagy örökségük. És ennek megvoltak a maga problémái, ugyanakkor lehetôvé tette számukra, hogy kidolgozzák a saját érdeklődési körüket és megfogalmazzák aggodalmaikat. Egyes általuk felvetett kérdések ma is érvényesek. Az egyik a filmkritika kérdése: vajon a filmtudománynak helyet kellene adnia az értékelésnek? Fóleg az 1910es és 1920-as években sok minden szól a film megnemesítésérôl: azáltal, hogy megtanítjuk, milyen lehet a film legjobb formájában, jobbá tesszük a mozit, és jobb nézóket hozunk létre. Tehát esztétikai tökéletesítésrôl van szó. Nem gondolom, hogy az én kurzusaim errôl szólnának. De érdekes, hogy akkoriban ez volt a modell.

Aztán ott van a filmkészítés szerepének állandó kérdése a kritikai gyakorlathoz képest. Sokan közülük forgatókönyvírást tanítottak. Ismételten, az esztétikai tökéletesítésrôl van szó: egy jól felépített forgatókönyv írásának a tanulmányozása azt is megtanítja, hogy milyen egy jól felépített forgatókönyv. Nincs sok képzési lehetôség a filmkészítés gyakorlati területein egészen a USC [University of Southern California] megalapításáig az 1920-as években. A gyakorlat és gyártás kérdése a kritikai elméletek tantervében azonban mindig is kérdéses volt a területünkön. Gyakran 
szakadék van a filmtudomány és a gyakorlati képzés, valamint a mesterképzés és az alapképzés között. Az általam ismert filmes képzésekben a mesterképzés tanterve lebontja az alapfogalmakat, amelyek megalapozzák az alapképzés tantervét. A mesterképzésen tehát az auteur romantikus eszméjének kritikájával foglalkozol, míg az alapszinten Hitchcockról, vagy az én esetemben, Hawks-ról tanulsz. Sok tennivaló van még a tantervekkel kapcsolatban.

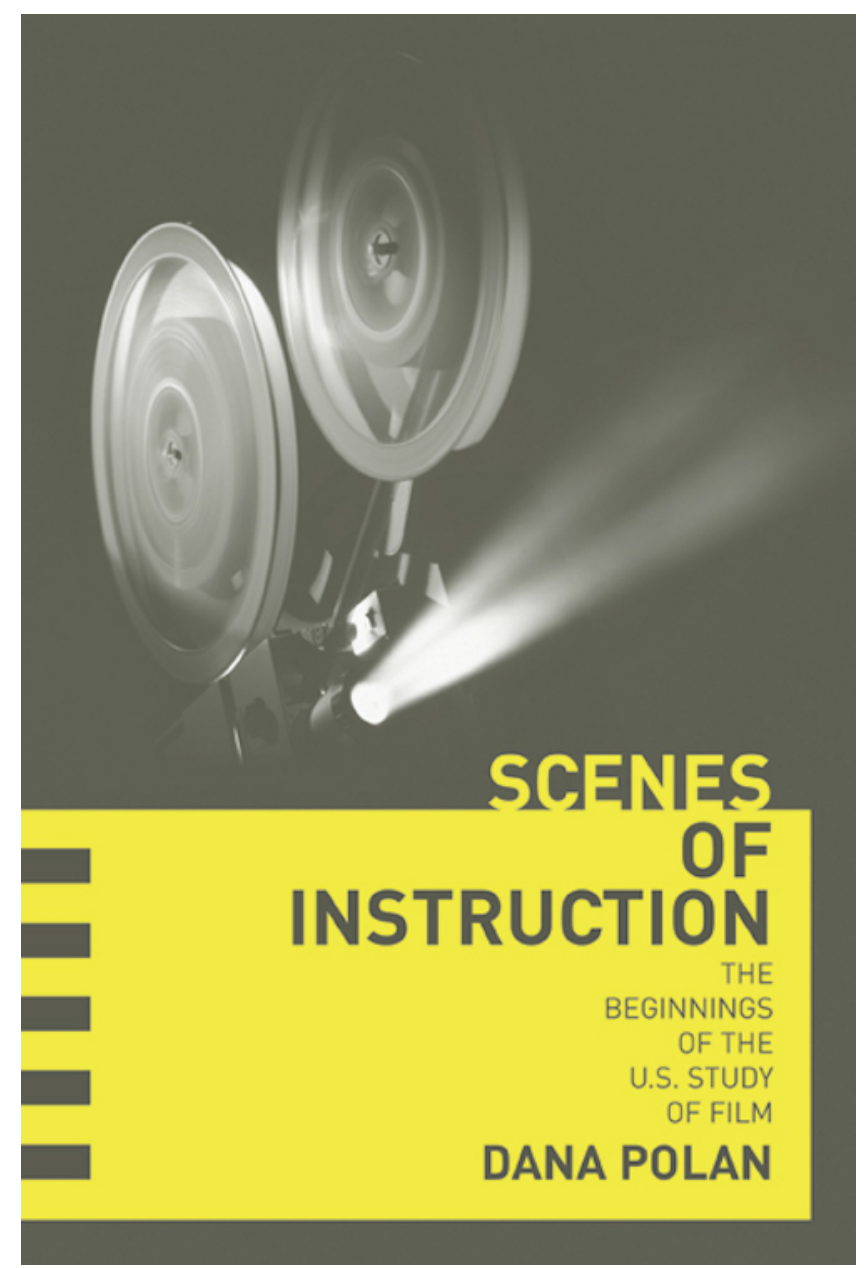

Dana Polan: Scenes of Instruction: The Beginnings of the US

$$
\text { Study of Film }
$$

DF: Hogy visszakanyarodjunk oda, ahonnan elindultunk, a mozi haláláról szóló beszélgetésünkhöz és a humán tudományok válságához: mindez a világ egy mélyebb szintú válságának tünete?

DP: Jó kérdés. Azt hiszem, a 2013-as chicagói SCMS-en volt, hogy felkértek, vegyek részt egy szekcióbeszélgetésen a mesterképzésekrôl és a professzionalizálódásról, ahol a humán tudományok válságának visszatérô trópusáról beszéltem. A krízist gyakran kezelik ciklikusként és elkerülhetetlenként. A történelem azonban nem ciklikus. A dolgok változnak, egy bizonyos pillanatban megtörténnek. Nem hiszem, hogy a humán tudományok mindig válságban lennének. A válság retorikája mindig jelen van, és semmi sem akadályozhatja meg, hogy egy adott pillanatban egy valós, konkrét, kiküszöbölhetetlen válság következzen be. Attól tartok, hogy a mi sajátságos konjunktúránkban olyan dolgok történhetnek a humán tudományokkal, amelyek nem ciklikusak, hanem specifikusak. A National Endowment for the Humanities [Humán tudományok 
Nemzeti Alapítványa] eltûnhet. A 2008-as gazdasági válság következményei az egyetemeken sokkal jelentôsebbek, mint más területeken, mert a nadrágszíj meghúzásának pillanatában alapos vizsgálódásnak vetik alá a humán tudományokat: szükségünk van-e erre a képzésre? Szükségünk van nôkutatásra? Ezek a jellemző kérdések mostanában. Sajnos, egy olyan pillanatban vagyunk, amikor a szülốk gyakran azt kérdezik, hogy „Mit fog ettôl a szaktól a gyermekem kapni?” A humán tudományok területén nagyon sajátos kényszerek érvényesülnek. Egyrészt a filmtudománytól a tágabb médiatudomány felé való fordulásnak megvan a jó oldala, de ennek egy része arról szól, hogy sokféle érintkezési lehetôséget biztosít a mozgóképekkel, hogy a hallgatók készségei szélesebb skálát fogjanak át. A tanszékemen tartunk egy Mobilmozi [Cellphone Cinema] címú kurzust. Ez egy gyártásorientált óra, és nagyon olcsó, mivel mindenki a saját telefonját használja, de mivel szakmai fortélyokról van szó, aggodalmat kelt bennem, mert nem vagyok biztos abban, hogy nekünk az a feladatunk, hogy a gyártói piacra készítsük fel a diákjainkat. Különben is, a legtöbb diák nem azt a fôszakot végzi el, amely szakmában késôbb elhelyezkedik, szóval nem a megfelelô készségeket adjuk át nekik.

Úgy gondolom, hogy a humán tudományoknak ellen kell állniuk a piaci igényeknek, szóval a tény, hogy a piac kezére játszunk, néha aggasztó. Nem tartom magam konzervatívnak, de a legszívesebben azt javaslom az amerikai hallgatóknak, hogy az alapszakot inkább kis szabad bölcsészetet oktató fôiskolákon végezzék el, mint a Mount Holyoke, az Antioch, az Oberlin, ahol a fogalmak széles skáláját tanítják, amelyeket sokféle módon használhatnak, némelyiket szakmailag, másokat pedig csak a világról való gondolkodáshoz. Nem vagyok a specializálódás híve, inkább a széles látókört, mintsem az elmélyített tudást részesítem elônyben több szempontból. A médiatudomány talán segít ebben, mint olyasvalami, ami nagyobb, mint a film, de tartok attól, hogy ez csak gyakorlati eszközöket ad az embereknek, melyeket a médiaiparban használhatnak. Az újmédiával foglalkozó oktatói álláspályázaton jóformán minden pályázónak volt egy olyan kurzusa, amelyen a diákoknak blogot kellett írni. Ami rendben is van, de azt gondoltam, hogy mi van, ha egy diák adornói értelemben ellenáll a blogírásnak? Rendszerint nem elvárt, hogy az ember olyan formával foglalkozzon, amelyet tanul vagy kutat, de olyan vélemény is van, hogy az újmédia tanulmányozása maga után vonja annak jóváhagyását is.

\section{DF: Nem csak jóváhagyásról van szó, hanem a rendszer múködésének logikájába való belépésrôl.}

DP: Ez visszavezet ahhoz, amit a kinevezés számszerúsítésérôl mondtam. Még szó sincs a tartalomról vagy a minôségről, de a blog már be van építve és mint forma jóvá van hagyva, mielốtt magáról a formáról gondolkodnánk.

DF: Játszhatnak-e szerepet a humán tudományok abban, hogy olyan kritikai eszközöket hozzanak létre, amelyekkel az emberek képesek lennének túllépni a piacositás és professzionalizálódás általános gondolkodásmódján?

DP: Az optimistább pillanataimban úgy gondolom, hogy a képek világában élünk, a filmtudomány pedig az a hely, ahol a képek erejét tanulmányozzuk. F.R. Leavis szerint az egyetem középpontja az angol nyelv és irodalom kell hogy legyen, mert arra tanít minket, hogy hogyan múködik a 
nyelv. A kommunikáció Amerikában sivár, számszerúsített területté vált napjainkban, épp ezért idônként úgy gondolom, hogy a kommunikáció kell hogy a fố tárgy legyen, mert üzeneteket tanulmányoz és azt, hogyan közvetítódik az információ egyik embertôl a másikig. Hasonlóképpen úgy gondolom, mindenkinek el kellene sajátítania valamiféle múveltséget a képek terén, a filmtudomány pedig ehhez járul hozzá. 9/11 után rengetegen mondták: bekapcsoltam a tévét, és az elsô gondolatom az volt, hogy filmet látok. Ezt a filmtudomány segíthet megérteni. És azt is, hogy filmként néztük, és a Közel-Keleten mindenkit a filmgonosz szerepébe castingoltunk. Egy természeti katasztrófa esetén nem tudjuk előre látni, milyen praktikus szükségletek adódnak: lehet, hogy orvosokra, mérnökökre vagy bakteriológusokra lesz szükség. De mindezeknek lesz képi megjelenítése is, a televízóban, az újságokban, és mi ezt elemezzük: a reprezentáció szerepét. Nem gondolom, hogy a reprezentációk másodlagosak lennének, tanulmányozni és elemezni kell ôket. Próbáltam ezt elkerülni a Hawks-kurzuson, mert nem akartam, hogy ez is csak a relevanciáról szóljon, de sok minden ott van Hawks-ban. Például a férfiasság iránti lelkesedése. Van egy liberális oldala. Az életrajzírói úgy gondolták, hogy valószínúleg republikánus volt, az biztos, hogy New Deal-ellenes. Nem arra akarok kilyukadni, hogy mindez Trumpot készítette elô. Az ember nem akarhatja meghamisítani a dolgokat, hogy azok lényegesnek túnjenek. De meg kell találni az összefüggéseket. Amerikának megvan a maga története, amely most szégyenteljes történetté vált. És érdemes lesz feltárni, hogyan jutottunk el idáig. Ennek pedig a filmek is részét képezik.

[A fordítás alapjául szolgáló kiadás: We Live in a World of Images. Contemporary Cinema Studies: A Discipline with a Future? Senses of Cinema, 2017. június. URL: http://sensesofcinema.com/2017/film-studies/dana-polan-interview/. A fordítást a kiadó engedélyével tesszük közzé.]

Fordította Kothencz-Török Katalin A fordítást ellenôrizte Füzi Izabella

\section{Jegyzetek}

1. A Y2K a 2000-es évre jósolt számítástechnikai katasztrófa [ $A$ ford.]

2. Dana Polan: The Futures-Market for Film Criticism. Film Criticism, 40.1 (2016. január). URL: https://quod.lib.umich.edu/f/fc/13761232.0040.125/-futures-market-for-filmcriticism?rgn=main;view=fulltext $[-A$ ford. $]$

3. D.P. a sajátosan amerikai „tenure” rendszerre utal: akinek sikerül teljesítenie az adott intézménynél a kinevezéshez szükséges publikációs és egyéb kívánalmakat, mielôtt lejárna a nagyjából a magyar tanársegédi beosztásnak megfelelố szerződése, a mi docensi fokozatunknak megfelelô „Associate Professor" kinevezést kapja meg, és az állandó szerzôdéssel járó anyagi és intézményi biztonságot. Ennél magasabb beosztás a „Professor” azaz „Full Professor”. A humán tudományokban a „tenure” kinevezés feltétele rendszerint egy nevesnek számító kiadónál publikált könyv, amelyet a kinevezésért felelôs bizottság tagjai külön értékelnek. Nem számít neves kiadónak az egyébként színvonalas köteteket is publikáló Mellen Press vagy a látszatra jó csengésú és szintén vegyes színvonalú, gyakran nem angolszász szerzốk múveit megjelentetố Cambridge Scholars Publishing Kiadó, mert ezeknél lazább a publikálást 
megelōzó szûrô. [- $A$ szerk.] 
(c) Apertúra, 2019. tavasz | www.apertura.hu

webcím: https://www.apertura.hu/2019/tavasz/fairfax-a-kepek-vilagaban-elunk-interju-dana-

polannel/

https://doi.org/10.31176/apertura.2019.14.3.1

(Q)opertúro 